\title{
Intravenous pentazocine dependence in a young sickle cell anemia patient: A case report
}

\author{
Aishatu Yusha'u Armiya'u, Bilkisu Ilah Garba, Dalha Gwarzo Haliru
}

\begin{abstract}
Introduction: Painful crisis is the most common manifestation of sickle cell anemia (SCA), hence rapid pain control and analgesia should be provided $[1,2]$. Pentazocine is a narcotic agonist/ antagonist analgesic commonly used in Nigeria for pain management in both medical and surgical conditions. Reports on opioid abuse/dependence amongst SCA patients are not commonly published, we report on a young SCA lady with pentazocine dependence seen at a psychiatric clinic. Case report: We report a case of a 17-yearold known SCA female with a six-month history of excessive use of pentazocine. She started selfinjection of pentazocine 18 months ago following a bone pain crisis and is said to have a strong desire to use the drug which she uses on daily basis. Initially, she started with $30 \mathrm{mg}$ daily but currently injects $60 \mathrm{mg}$ bd. She has developed hyperpigmented macules with indurations and scarification marks on both forearms. A diagnosis of pentazocine dependence with mild depression in a sickle cell anemia patient was made. She was admitted at the drug unit and managed accordingly. Conclusion: Health care
\end{abstract}

Aishatu Yusha'u Armiya'u', Bilkisu llah Garba², Dalha Gwarzo Haliru $^{3}$

Affiliations: ${ }^{1}$ MBBS, MWACP, FMCPsych, Department of Psychiatry, Jos University Teaching Hospital, Jos. Plateau State, Nigeria; ${ }^{2} \mathrm{MBBS}$; Dip Allerg; MSc Med; FMCPaed, Department of Paediatrics, Yariman Bakura Specialist Hospital Gusau. Zamfara State, Nigeria; ${ }^{3}$ MBBS, FMCPath, Department of Haematology and blood transfusion, Bayero University Kano. Kano State, Nigeria.

Corresponding Author: Dr Armiya'u Aishatu Yusha'u, MBBS, MWACP, FMCPsych, Department of Psychiatry, Jos University Teaching Hospital, Jos. Plateau State, Nigeria; Email: aarmiyau@gmail.com

Received: 07 November 2015

Accepted: 08 January 2016

Published: 04 March 2016 workers should be sensitized on the dangers of analgesic abuse especially in patients with sickle cell anemia. All patients with chronic pain that require long duration of analgesic drugs should be counseled on the symptoms of dependence and informed to report immediately to their doctors.

Keywords: Dependence, Pain, Pentazocine, Sickle cell anaemia

\section{How to cite this article}

Armiya'u AY, Garba BI, Haliru DG. Intravenous pentazocine dependence in a young sickle cell anemia patient: A case report. Case Rep Int 2016;5:1-4.

\section{Article ID: $100020 C R I N T A A 2016$}

$$
* * * * * * * * *
$$

doi:10.5348/crint-2016-20-CR-1

\section{INTRODUCTION}

Painful crisis is the most common manifestation of sicklecellanemia(SCA) which may requirehospitalization. Rapid pain control and analgesia should be considered as an initial management. This can be achieved and maintained with long acting oral or parenteral drugs $[1$, 2] with provision for bolus analgesia if breakthrough pain occurs [1]. The choice of analgesia depends on how far along the analgesic ladder the patient has progressed and opioids are used for severe pain in SCA [1].

Pentazocine is a narcotic agonist/antagonist analgesic commonly used in Nigeria for pain management in both medical and surgical conditions. It is often used in the management of vaso-occlusive crisis in sickle cell anemia patients [3]. It has some dysphoric effect but produces little or no euphoria and was initially thought to be non- 
addictive, however, it is commonly abused [3]. Reports on opioid abuse/dependence amongst SCA patients are not commonly published, we report on a young SCA female with pentazocine dependence seen at a psychiatric clinic.

\section{CASE REPORT}

A 17-year-old secondary school graduate residing at Bukuru in Jos, Nigeria presented to the Psychiatric outpatient department on account of excessive use of pentazocine for six months. She is a known sickle cell anemia patient and said to have a strong desire to use pentazocine which she injected intravenously (occasionally intramuscularly) herself on daily basis.

She started abusing pentazocine 18 months ago, following a bone pain crisis for which intravenous pentazocine (first ever dose) was prescribed by her physician for pain relief. Then she was given $30 \mathrm{mg}$ of pentazocine daily for two weeks and she reported feeling good after the medication with all her pains disappearing. After treatment she started abusing medication by selfadministration, primarily intravenous injection into her upper limbs bilaterally. In the last six months, she increased the dose of pentazocine from initial $30 \mathrm{mg}$ daily to $30 \mathrm{mg}$ twice daily (first dose in the morning and second dose just before she went to bed); she now administers 60 mg twice daily.

Initially, she spent about one thousand naira (about $\$ 5.00)$ per day to purchase pentazocine from pharmacy without prescription which increased to about four thousand naira (about \$17.00) with increasing amount of pentazocine (30 mg to $120 \mathrm{mg}$ ), other times she stole medicines from her mother's patent store. To continue her drug using behavior, she sourced money by stealing from her mother, or lying to her elder sister to give her money for other reasons. Whenever she did not use the drug, she experiences flu-like symptoms and intense craving for the drug which stops once she injected herself. She had to use the drug daily to be able to have a good day despite evidence of scars on her upper limbs bilaterally which she used long sleeve shirts to cover up to prevent her family from asking questions. Recently, her mother noticed her upper limbs and asked her questions, since then patient became withdrawn, low mood, refusal to eat which prompted for this consultation.

She was diagnosed with SCA with electrophoretic pattern of HbSS at the age of 2 years, and was neither adherent with Proguanil Hydrochloride and folic acid nor regular with follow-up visit. Prior to her commencement of the abuse of pentazocine, she experienced crisis about 8-9 times/annually relieved with tramadol or ibuprofen. Last bone pain crisis was 18 months ago when she was given the first dose of pentazocine.

The patient was admitted five months ago following similar complaints for two weeks at Jos University Teaching Hospital (JUTH). She was discharged to continue treatment as an outpatient with weekly psychological sessions and was abstinent for four months. Her last visit to the hospital was six days prior to current presentation.

She was the only SCA patient in a monogamous setting of six children. Her father died 14 years ago while her mother is a retired nursing officer currently working with a nongovernmental organization (NGO). The mother owns a patent medicine store from where the patient went to get pentazocine most times. Her academic performance was not affected as she graduated college with five $\mathrm{C}$ grades and $3 \mathrm{~B}$ grades including Mathematics and English language.

Mental state examination revealed a young lady, calm, cooperative though sobbing and appeared reluctant for treatment. Her speech was coherent but hesitant with low tone, her mood was dull. There was no abnormality in stream, form, content, and possession of thought, she had no hallucinatory experiences. She was conscious, alert, oriented in time, place and person. Her attention and concentration were intact; judgment was poor but had full insight into her problem.

Physical examination found her to be normal for age, mildly pale and icteric, bossing of the forehead, with slight protrusion of abdomen. She had hyperpigmented and indurated macules (from needle pricks) and generalized hypertrophy on the anterior and medial aspect of both forearms as shown in Figure 1. No complications of SCA were seen.

A diagnosis of pentazocine dependence with mild depression in a sickle cell anemia patient was made.

The patient had normal electrolytes, urea/creatinine and liver function test, while retroviral screening, Hepatitis-BsAg, Hepatitis C virus and pregnancy test were negative. Full blood count showed leukocytosis (white

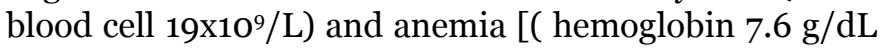
(11-16), haematocrit [HCT] $21.7 \%(37-50)$ and red blood cells $\left.[\mathrm{RBC}] 2.44 \times 10^{12} / \mathrm{L}\left(3.50-5.50 \times 10^{12} / \mathrm{L}\right)\right]$. She was admitted into the drug unit of JUTH for detoxification and drug management. She was co-managed by the psychiatrist, pediatrician and hematologist and was

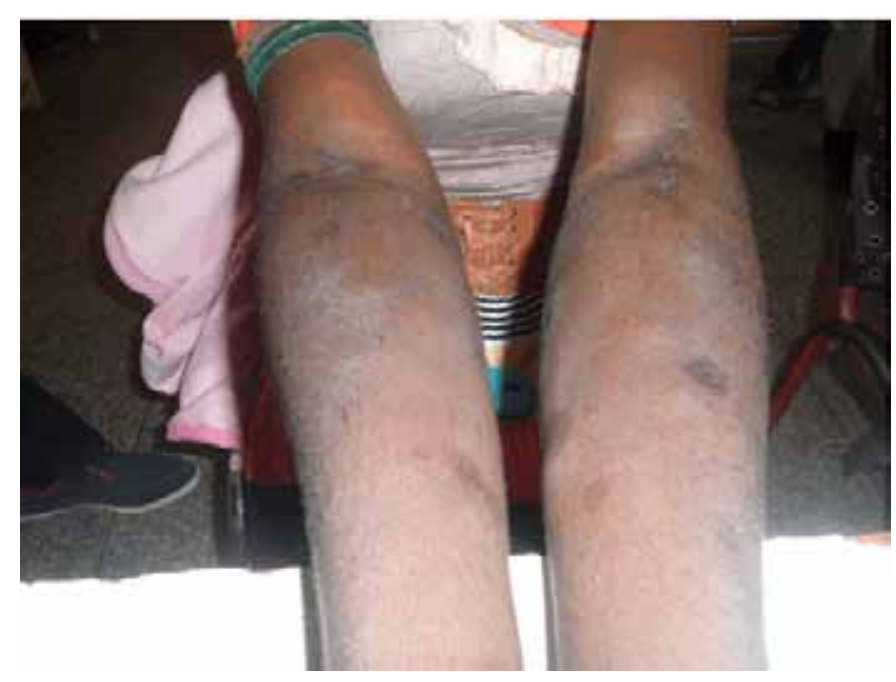

Figure 1 Hyperpigmentation and indurations on both forearms. 
placed on sodium valproate $200 \mathrm{mg}$ bd and fluoxetine 20 $\mathrm{mg}$ daily to continue with the paludrine and folic acid.

She was monitored closely where she had series of psychological sessions and counseling. She was discharged after one month having satisfied some set goals such as improved health, elimination of drug in her system, reduction of potential harm to self and hazards to public health. This was based on reports from clinical interview with patient, counseling sessions and reports from ward staff and relatives of patient. She was referred to the outpatient clinic for continuation of counseling sessions, rehabilitation and maintenance of a drug free life/behavior.

\section{DISCUSSION}

Sickle cell anemia is an inherited disorder of hemoglobin structure that is not curable in adults, but in selected children cure is achieved using allogeneic bone marrow transplantation or cord blood transplantation $[4,5]$. Sickle cell anemia is a quadrumvirate of pain syndrome, anemia and its sequelae, organ failure including infection and comorbid condition [2]. However, pain is the main feature of SCA and dominates its clinical picture throughout the life of the patient. Our patient experiences about 8 to 9 episodes of pain annually which were relieved with tramadol or Ibuprofen. Pain in SCA patient may precipitate or be itself precipitated by the other three components of the quadrumvirate [2]. Pain management in SCA must be within the framework of the disease as a whole and not in isolation. Our patient had her first dose ever of pentazocine 18 months ago following a severe bone crisis which was one component of SCA; it is possible that only the pain was targeted and not the whole disease.

Medical management of persistent pain often requires multiple medications that act on a variety of neurochemical pathways and comorbid mental health issues such as depression or anxiety which can occur should be addressed [6].

Our patient had low levels of Hb, RBC and HCT; which are common findings in such patients. However, she was not regular at her follow-up visit and was not regular with her routine drugs which can also explain the anemia since folic acid helps in building up the hemoglobin.

Her physician introduced pentazocine for her pain which gave her fast relief and she also had euphoric effect as she felt happy. Pentazocine is a synthetic agonist-antagonist narcotic (opioid analgesic) drug of the benzomorphan class of opioids [3]. It is used in the treatment of moderate to severe pain and can cause analgesia, euphoria and sedation [3] These effects were made our patient to be taking two doses in order to make her feel good to start her day and the night dose to make her calm and be able to sleep. It is important to note that an opioid drug was prescribed genuinely for the patient due to need for the drug (severe bone crisis). The patient was initially naive to the drug, but with the euphoric effect and deep sense of pain relief; she continued self-injecting herself and became addicted using the drug not only for pain relief but for its other properties.

Two similar cases of pentazocine abuse seen in a psychiatry clinic at the University of Ilorin Teaching Hospital (UITH) Ilorin, Nigeria were reported [3]. Both cases were sickle cell anemia patients whom were first given intramuscular pentazocine in private hospitals during an episode of bone pain crises [3]. Despite the fact that the bone pain crises subsided after a few days on admission, they continued to feign pains so as to receive pentazocine because they enjoyed its dysphoric effect. They also had features of pentazocine dependence which our case had which included intense craving for the drug, signs of needle pricks on the body, stealing money and poor academic performance (although the academic performance of our case was not affected).

Sickle cell anemia alone may predispose a family to physical, psychosocial and financial stress [3]. The presence of a co-morbidity of sickle cell anemia and drug dependence might further affect their clinical and psychological states [3]. The drug dependent patient continues to inject pentazocine in order to alleviate or eliminate withdrawal symptoms [3]. In order to sustain and fund the drug habit, our case had to engage in antisocial behaviors i.e., stealing, begging, and lying. There is therefore, a need to ensure careful use of analgesics with addictive potential in these patients in order to minimize societal cost of health [3].

\section{CONCLUSION}

Health care workers should be sensitized on the dangers of analgesic abuse especially in patients with sickle cell anemia. All patients with chronic pain that require long duration of analgesic drugs should be counseled on the symptoms of dependence and informed to report immediately to their doctors. Drug units which should be separate from the general psychiatric ward should be made available in all hospitals that attend to psychiatric patients to ensure optimal detoxification and rehabilitation. The government and health professional bodies should ensure strict compliance with sale of controlled drugs.

$$
* * * * * * * * *
$$

\section{Author Contributions}

Aishatu Yusha'u Armiya'u - Substantial contributions to conception and design, Acquisition of data, Analysis and interpretation of data, Drafting the article, Revising it critically for important intellectual content, Final approval of the version to be published

Bilkisu Ilah Garba - Analysis and interpretation of data, Revising it critically for important intellectual content, Final approval of the version to be published 
Dalha Gwarzo Haliru - Analysis and interpretation of data, Revising it critically for important intellectual content, Final approval of the version to be published

\section{Guarantor}

The corresponding author is the guarantor of submission.

\section{Conflict of Interest}

Authors declare no conflict of interest.

\section{Copyright}

(C) 2016 Aishatu Yusha'u Armiya'u et al. This article is distributed under the terms of Creative Commons Attribution License which permits unrestricted use, distribution and reproduction in any medium provided the original author(s) and original publisher are properly credited. Please see the copyright policy on the journal website for more information.

\section{REFERENCES}

1. Rees DC, Olujohungbe AD, Parker NE, Stephens AD, Telfer P, Wright J. Guidelines for the management of the acute painful crisis in sickle cell disease. $\mathrm{Br} \mathrm{J}$ Haematol 2003 Mar;120(5):744-52.

2. Ballas SK. Current issues in sickle cell pain and its management. Hematology Am Soc Hematol Educ Program 2007:97-105.

3. Makanjuola AB, Olatunji PO. Pentazocine abuse in sickle cell anaemia patients: a report of two cases vignettes. Afr J Drug Alcohol Studies 2009;8(2):5964.

4. Walters MC, Patience M, Leisenring W, et al. Bone marrow transplantation for sickle cell disease. N Engl J Med 1996 Aug 8;335(6):369-76.

5. Gore L, Lane PA, Quinones RR, Giller RH. Successful cord blood transplantation for sickle cell anemia from a sibling who is human leukocyte antigen-identical: implications for comprehensive care. J Pediatr Hematol Oncol 2000 Sep-Oct;22(5):437-40.

6. Dampier C, Haywood C Jr, Lantos J. A "narcotics contract" for a patient with sickle cell disease and chronic pain. Pediatrics 2011 Jul;128(1):127-31.
Access full text article on other devices

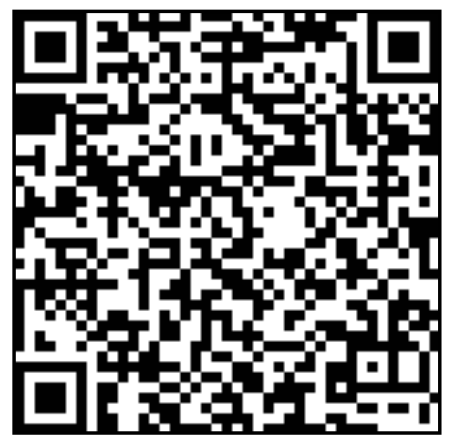

Access PDF of article on other devices

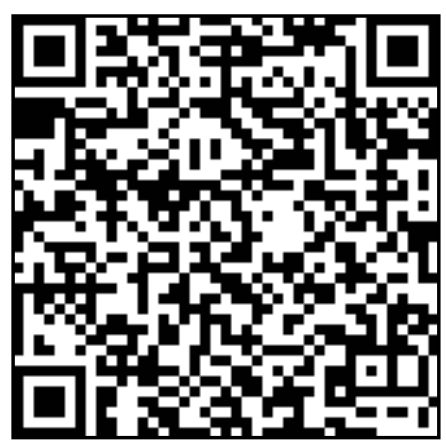

